\title{
Meios e audiências: a emergência dos estudos de recepção no Brasil
}

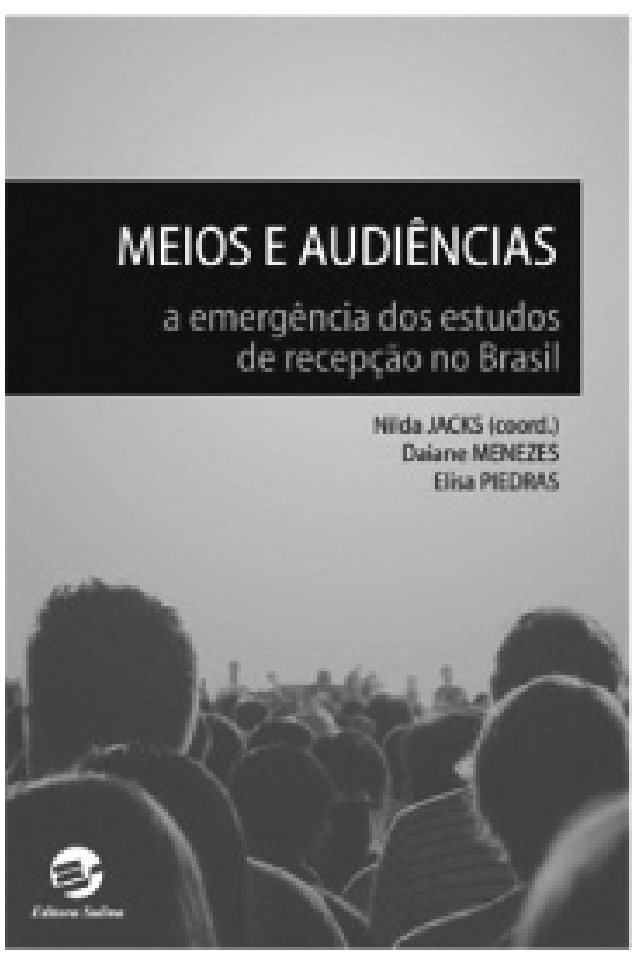

JACKS, Nilda (Coord.); MENEZES, Daiane \& PIEDRAS, Elisa. Meios e audiências: a emergência dos estudos de recepção no Brasil. Porto Alegre: Sulina, 2008.

\section{Graça Craidy}

Doutoranda no Programa de Pós Graduação em Comunicação Social na PUCRS/RS/BR

gcraidy@uol.com.br
Recepção sem tapa-olhos. Quem assina o prefácio é um dos papas da recepção latino-americana, respeitado metodologista no campo da comunicação e o autor com maior impacto nas pesquisas do livro Meios e Audiências (2008): o espanhol Jesus Martín-Barbero. O celebrado autor de Dos meios às mediações (2003), que vive há quase meio século na Colômbia, aproveita o espaço para reconhecer também o valor da pesquisa brasileira, reputando-a como a mais inserida no estudo da formação histórica da cultura nacional, na América Latina.

Barbero elogia o tratamento justo do livro à pluralidade das visões e à revelação da heterogeneidade social do Brasil, mostrando-se encantado com o "grande e denso país que aparece entre suas linhas e nos seus intermeios" (p.14). Ele louva também a abertura ao debate metodológico do campo da comunicação para além do dualismo e aplaude a não-complacência das autoras com o que chama de: 1 . "teoricismos disfarçados de pesquisa qualitativa para mascarar a ausência de referenciais da realidade"; 2 . "incapacidade de formular conceitualmente o lugar a partir do qual construir o problema do conhecimento"; 3. "escapismos e modas teóricas" que fragilizam epistêmica e metologicamente o ainda carente campo científico da comunicação (p.12).

Meios e Audiências (2008) é coordenado pela pesquisadora de Estudos Culturais da Universidade Federal do Rio Grande do Sul (UFRGS), Nilda Jacks, que integra a equipe de autoras junto com suas orientandas Daiane Menezes e Elisa Piedras.

\section{Este outro, o receptor}

Já na primeira epígrafe do livro Meios e Audiências, o receptor é apresentado aos olhos contemporâneos bem diferente do visto pelos antigos tapa-olhos - ditos "ideologizados" - dos anos pré 90. Fica-se sabendo que a recepção é um processo que não acontece apenas ali, na hora da interação com o meio de comunicação. Que começa muito antes do sofá. E que termina bem depois de o receptor desligar a TV. Na verdade, a recepção é construída "no tempo longo da formação do habitus (Bourdieu), dos gostos e dos valores" (p.13), explica Barbero, no prefácio, reportando-se à outra pesquisa de Jacks sobre recepção no Brasil, publicada no livro Querência: cultura regional como mediação simbólica (1999).

Para Jacks, a recepção se funde com as práticas cotidianas. É negociada com outros significados do repertório do receptor: os que ele recebeu da família, da escola, da religião, do partido político, da empresa, etc. E muda de figura também conforme o gênero, a idade, 
a geografia, a história, a economia, a identidade, etc. Só então, a mensagem com que o receptor foi impactado é digerida, enfim, como sua.

Meios e Audiências, com suas provas empíricas pinçadas de pesquisas de comunicação produzidas nos anos 90, em todo o Brasil, revela o endosso dessa maneira vanguardista de entender o receptor. E o novo que se firma como avanço do ponto de vista dos estudos de recepção, segundo as autoras, atende pelo nome de "mediação". Faz a ponte de mil e um jeitos entre o emissor e o receptor, sobre toda e qualquer mensagem dos meios de comunicação. Seja rádio escutado por uma tribo indígena no planalto central ou TV apropriada por uma agricultora mais velha. Seja recepção pelo viés da educação observando estudantes mineiros ou pelo viés da música, em um espaço amazonense. Seja um metalúrgico aboletado em audiência da novela das oito, uma criança carente brincando de casinha com a TV, um adolescente piracicabano usando TV como companhia ou um pelotense construindo um papel social para o vilão novelesco. O novo atende pelo nome também de "múltiplos receptores".

\section{9 olhares sobre recepção}

Múltiplas mediações, múltiplos receptores, múltiplas articulações. É disso que trata o livro Meios e Audiências, em sua revelação do estado de arte da pesquisa de recepção no Brasil, nos anos 90. Mostra que pontes são essas que unem emissor e receptor. Quem elas conectam? Como se atravessam? Do que se desviam? Revela a pluralidade e a não-passividade do receptor do fim do século passado, multifacetado e certamente diferente do homogêneo e dito indefeso receptor de antes da década de 90 .

\section{(0 livro) revela a pluralidade e a não-passividade do receptor do fim do século passado, multifacetado e certamente diferente do homogêneo e dito indefeso receptor de antes da década de 90.}

Jacks, Menezes e Piedras usaram como pista para suas fontes os dois livros de Caparelli e Stumpf, Teses e dissertações em comunicação no Brasil, publicados em 1998 e em 2001, que fazem - via resumos - o inventário das teses e dissertações de 1992 a 1999 do campo da comunicação, no Brasil. É bom que se enfatize: Meios e
Audiências trata apenas de teses e dissertações, apenas de comunicação, e apenas de recepção.

As autoras repescaram as 49 pesquisas que tratavam de recepção, organizando-as segundo o critério de abordagens proposto por Ana Carolina Escosteguy, sobre o mesmo corpus, em Mídia.BR (2004): 32 pesquisas com abordagem sociocultural (que considera as relações sociais e culturais), 9 pesquisas com abordagem comportamental (que estuda as reações do público ao estímulo midiático) e 4 pesquisas com outras abordagens (que abrange desde agenda setting até revisões teóricas, como a nova "teoria plural do espectador cinematográfico").

Na hora de mergulhar em cada uma das 49 pesquisas, o trio inspirou-se no modelo de análise proposto por Maria Immacolata Lopes em seu livro Pesquisa em Comunicação (1990) e acrescentou outras categorias. Esse modelo hibridizado permitiu identificar: 1 . problemas e objetos de pesquisa; 2 . hipóteses, procedimentos e técnicas; 3. modelos teórico-metodológicos; 4. premissas teóricas, metodológicas e epistemológicas; 5 . limites, lacunas e avanços do conjunto de pesquisas; 6 . principais resultados; 7. insights para futuras apropriações acadêmicas.

Dessa forma, Jacks, Menezes e Piedras dedicaram-se a debulhar não só as múltiplas abordagens e a diversidade dos objetos, mas esmiuçaram rigorosamente tudo o que lhes pareceu relevante em recepção. E, em alguns casos, tudo de novo mais uma vez, quando analisaram a mesma pesquisa a partir de lugares diferentes, ora sob o ponto de vista da mediação do gênero, ora sob a mediação da localização geográfica, ora como classe social, entre outras.

\section{Elogios e críticas}

Não sobrou pedra sobre pedra. Do mesmo jeito que as pesquisas renderam delicados elogios, amargaram pesadas críticas. Os elogios: o desengessamento do receptor e da sua suposta passividade; a concepção de cultura como modo de vida e mediação decisiva na recepção; a escolha do filtro metodológico cultural das mediações e multimediações propostas por Barbero e Orozco, entre outros; o olhar menos preconceituoso com a TV; a compreensão de classes além da diferenciação social; a contribuição de outros campos do conhecimento; a escolha de receptores antes pouco estudados - como adolescentes e agricultoras, por exemplo; as abordagens originais, como o uso social do vilão, o estudo de personagens ou a importância do som na telenovela, entre outros; a citação textual das falas em vez de apenas referir-se a elas, como se fazia antigamente; o uso inovador da análise semiótica na interpretação das respostas dos receptores; os estudos comparativos; a exuberância de dados empíricos.

As críticas se referem, em sua maior parte, à falta de rigor científico e à quase total ausência de diálogo com 
trabalhos já realizados, revelando que os pesquisadores analisados estão, como enfatizam as autoras, "de costas para a comunidade científica" (p.295). E as questões se sucedem. Onde estão as premissas sobre o emissor, sobre o gênero, sobre os meios de comunicação? Por que não se esgotou antes o estado de arte do campo, naquele determinado enfoque, para não desperdiçar esforços em requentadas conclusões? Que interdisciplinaridade é essa que nunca se cruza com outras disciplinas?

Por que não se analisou semioticamente o discurso do receptor, lapidando seus sentidos, em vez de simplesmente inseri-lo no texto, como mera citação? Que amostra é essa que não consegue representar o grupo? Que método é esse que simplesmente cola os saberes alheios e não ajuda a apontar nada de novo? Por que é que no lugar do quadro teórico construído para enfrentar o problema da pesquisa só se encontra a revisão bibliográfica? Quem disse que entrevista e questionário é a mesma coisa? Por que não cruzar os dados qualitativos da academia com os dados quantitativos já disponíveis no mercado? Afinal, é uma pesquisa ou ensaio? E onde está o capítulo metodológico?

\section{As novidades dos anos 90}

O panorama propiciado pelo minucioso trabalho das três autoras, embora analisando descobertas colhidas há no mínimo dez anos, quando ainda nem havia explodido o boom da internet, anuncia contextualmente dados bastante interessantes, que indicam com clareza a evolução do pensamento científico no trato da recepção. Como já se disse, a começar pelo olhar ao próprio receptor, que assume a sua voz como sujeito e neutraliza bastante a anterior crença de estar sempre à mercê de uma suposta perigosa manipulação dos meios, na verdade, muito mais relacionada a estética, consumo e endosso de opiniões já consolidadas, apontam as pesquisas.

A obra Meios e Audiências revela: até os adolescentes têm espírito crítico em relação ao que os meios afirmam. A tão temida relação das crianças com a TV apresentase nem tão temível, já que as crianças a utilizam como "contadora de histórias" (em substituição à omissão dos adultos como narradores), usada também como uma ferramenta para ampliar a sua imaginação. Isto é: a criança se apropria da mensagem e a transforma, conforme a sua criatividade. As pesquisas fazem um alerta, porém: o espírito crítico infantil é bastante baixo e tende a acreditar em tudo o que é dito na TV, necessitando da mediação dos adultos. TV e rádio, nessa ordem, são os meios mais estudados, o rádio considerado um veículo mais de utilidade pública, para criar solidariedades e entreter, enquanto a TV definitivamente tomou posse de todas as casas, em lugar de honra, transformada para sempre em bicho de estimação.

Sobre telenovela - o gênero mais estudado - a pesquisa revela que o som, por exemplo, tem importância fundamental: que pode haver um olhar desatento, mas nunca um ouvir desatento. Seus vilões funcionam como mote para discutir questões coletivas ou endossar opiniões pessoais. Sobre publicidade, por exemplo, surge que as receptoras carentes se interessam muito mais por alimentos e lojas populares, do que por jóias, perfumes e carros importados, estranhos ao seu universo. A receptora rural, por sua vez, ainda privilegia o saber fazer no lugar do poder comprar e, entre os agricultores em geral, há uma percepção de superioridade moral em comparação com seus pares urbanos - ser é melhor do que ter - rechaçando o que não se afina com seus valores e crenças, inclusive informações científicas.

\section{Os adolescentes têm espírito crítico em relação ao que os meios afirmam. A tão temida relação das crianças com a TV apresenta-se nem tão temível, já que as crianças a utilizam como "contadora de histórias".}

A TV a cabo revela um novo receptor de consumo individual da programação, solitário e desejoso de mundialização, que, no entanto, hibridiza a sua globalidade com notícias de canais abertos locais. As escolas, dizem as pesquisas, têm inveja da TV. Por quê? A TV transmite conhecimento em curto espaço de tempo e prende a atenção das crianças, deixando a escola cada vez mais chata.

Enfim, são muitas as descobertas reveladas por Meios e Audiências, mais ainda quando vistas assim, em conjunto, o suco de uma década atravessado por tantos olhares e indagações. A obra de Jacks, Menezes e Piedras é uma fonte confiável, rica e fundamental para quem quer fazer pesquisa séria sobre recepção no Brasil. Basta, como as autoras, dispensar o tapa-olhos wamecos 